\title{
INCIDENCE OF RESPIRATORY VIRUSES IN PRETERM INFANTS SUBMITTED TO MECHANICAL VENTILATION
}

\begin{abstract}
SUMMARY
The objectives of this study were to determine the incidence of infection by respiratory viruses in preterm infants submitted to mechanical ventilation, and to evaluate the clinical, laboratory and radiological patterns of viral infections among hospitalized infants in the neonatal intensive care unit (NICU) with any kind of acute respiratory failure. Seventy-eight preterm infants were studied from November 2000 to September 2002. The newborns were classified into two groups: with viral infection (Group I) and without viral infection (Group II). Respiratory viruses were diagnosed in 23 preterm infants (29.5\%); the most frequent was respiratory syncytial virus (RSV) (14.1\%), followed by influenza A virus (10.2\%). Rhinorrhea, wheezing, vomiting and diarrhea, pneumonia, atelectasis, and interstitial infiltrate were significantly more frequent in newborns with nosocomial viral infection. There was a correlation between nosocomial viral infection and low values of C-reactive protein. Two patients with mixed infection from Group I died during the hospital stay. In conclusion, RSV was the most frequent virus in these patients. It was observed that, although the majority of viral lower respiratory tract infections had a favorable course, some patients presented a serious and prolonged clinical manifestation, especially when there was concomitant bacterial or fungal infection.
\end{abstract}

KEYWORDS: Respiratory viruses; Preterm infants; Nosocomial infection.

\section{INTRODUCTION}

Viral infections are probably responsible for more nosocomial infections than previously realized; it is considered that at least $5 \%$ of all nosocomial infections are due to viruses, but this is apparently an underestimate ${ }^{33}$. The risk for nosocomial acquisition of viral lower respiratory tract infection increases during epidemics ${ }^{3,9}$.

The role of respiratory viruses in nosocomial infections is sometimes little recognized, due to the technical difficulty encountered by many services in identifying these agents and the nonspecific clinical presentation of these infections during the first year of life. Respiratory syncytial virus (RSV) is the most common viral pathogen during infancy ${ }^{4}$.

Severe viral infections may occur in previously healthy infants and young children, although preterm infants and patients affected by cardiac, pulmonary, or immune system disturbances are at greater risk, and also reinfection is more frequent in these patients ${ }^{1,31}$.

The frequency of infection due to respiratory viruses in neonates has not been fully clarified and to date there are few works in the literature describing these viruses in the neonatal period ${ }^{6,35}$. It is important to emphasize the need for an early etiological diagnosis in order to choose appropriate therapeutics and control the spread of viral pathogens within neonatal intensive care units (NICUs).

The objectives of this study were to determine the incidence of infection by respiratory viruses (RSV; parainfluenza viruses 1, 2 and 3; influenza A and B viruses; and adenovirus) in preterm infants submitted to mechanical ventilation, and to evaluate the clinical, laboratory and radiological patterns of viral infections among hospitalized preterm infants in the NICU with any kind of acute respiratory failure.

\section{MATERIAL AND METHODS}

Seventy-eight preterm infants were admitted to the NICU with acute respiratory failure and submitted to mechanical ventilation, from November 2000 to September 2002.

Ethical Guidelines: The present study was approved by the Ethical Commission of Hospital das Clinicas da Faculdade de Medicina, Universidade de São Paulo, and informed written consent was obtained from parents or legal guardians of participants. A newborn lung disease protocol, which includes specific diagnosis for respiratory viral pathologies, was completed for each neonate. 
The specific examinations were performed by the Laboratory of Respiratory Viruses, Adolfo Lutz Institute, São Paulo. The tracheal aspirates were collected at the time of hospital admission, and every seven days during the mechanical ventilation period, by vacuum suction through a plastic catheter with a specimen trap and submitted to rapid evaluation (by antigen detection) for verification of the presence of respiratory viruses (RSV; parainfluenza viruses 1, 2 and 3; influenza $\mathrm{A}$ and $\mathrm{B}$ viruses; and adenovirus). This evaluation was performed through indirect immunofluorescence assay (IFA) with monoclonal antibodies from the Respiratory Viruses Panel I Viral Screening \& Identification Kit (Chemicon, Temecula, CA, USA) (sensitivity: 70$90 \%$ and specificity: greater than $95 \%$ ), and isolation and identification of viruses (sensitivity: 60-90\% and specificity: 100\%), which were performed in four kinds of cell culture, namely: Hep-2 (human epithelial carcinoma); NCI-H292 (human lung carcinoma); MDCK (Madin-Darby canine kidney); and VERO (African green monkey kidney) cell cultures. In this manner, it was intended to reduce false-negative results to the minimum. The presence of respiratory viruses was confirmed by IFA in cultures with possible cytopathic effect. Viral infection was diagnosed whenever the two diagnostic methods, IFA or viral culture, gave a positive result.

Infection was said to have been acquired nosocomially when the previous tracheal secretion was negative for respiratory viruses. We considered the incidence of respiratory viruses in preterm infants submitted to mechanical ventilation to be the proportion of newborns infected during the hospital stay.

Throughout the study period, at the time of admission to the NICU and whenever necessary, venous blood samples were collected from all neonates included in the protocol for culture of aerobic bacteria and fungi. The concentration of C-reactive protein (CRP) (immunonephelometry) was also determined from blood samples. CRP values $>40 \mathrm{mg} / \mathrm{L}$ were considered suggestive of bacterial or mixed viralbacterial infection ${ }^{18,27}$. Chest radiographs were done when necessary.

The patients were classified into two groups, according to the presence or absence of viral infection: Group I, comprising infants with viral infection and Group II, patients without viral infection.

The NICU consists of one large central room with a capacity of 18 cots or incubators. In addition, there are two isolation rooms that may be used for infants requiring intensive or special care. Babies are nursed in cots or incubators, depending on their condition and maturity at the time of admission. When babies are in incubators, most of the routine care is given through ports.

During periods of increased RSV and influenza prevalence in the community, infants with respiratory illness admitted to the hospital are placed in isolation rooms or together with other infants with viral respiratory illness. Mothers are encouraged to visit their babies and to breast-feed or produce expressed breast milk. Hand-washing with soap and water up to the elbow is required between contact with patients. Nursing staff and doctors wear gowns when in the unit. Face masks are not worn routinely, except when carrying out special procedures and when the staff and visitors have acquired a respiratory infection.

Statistical analysis: The comparison of proportions was performed with the Fisher's exact test for the categorical variables. The MannWhitney test was used to compare medians of the continuous variables. Values of $p$ less than 0.05 were considered significant. Analyses were performed using the software SPSS for Windows, version 8.0.

\section{RESULTS}

A total of 78 preterm infants with acute respiratory failure and submitted to mechanical ventilation were included in the study, and nosocomial viral infection was identified in 23 cases $(29.5 \%)$. RSV was found in 11 patients (14.1\%), followed by influenza A virus in eight $(10.2 \%)$, RSV with influenza A virus in two (2.6\%), influenza A virus with parainfluenza 3 in one $(1.3 \%)$, and RSV with parainfluenza 1 in one infant $(1.3 \%)$. There was no case of infection by influenza B, adenovirus or parainfluenza 2. In 45 neonates with pneumonia $(84.9 \%)$ at least one pathogen was isolated (Fig. 1).

The characteristics of the preterm infants studied are summarized in Table 1. In relation to sex, gestational age, birth weight, weight at admission, duration of oxygen therapy and mechanical ventilation no statistically significant differences were found between the two groups. However, the group without viral infection (Group II) was associated with a lower age at hospital admission. Nosocomial viral lower respiratory tract infection was acquired at a median age of nine days after admission with a range of seven to 27 days. The median age at the onset of infection was 25 days with a range of eight to 28 days.

All neonates had undergone previous hospitalization and 46 (59\%) had been treated with antibiotics, corresponding to eight $(34.8 \%)$ from Group I and 38 (69.1\%) from Group II. The clinical manifestations of the preterm infants are shown in Fig. 2. The most common admitting diagnose in these newborns was respiratory distress syndrome $(\mathrm{n}=61$, $78.2 \%)$.

The radiological and laboratorial data of the newborns are provided in Table 2. There was an association between viral infection and interstitial infiltrate. The CRP level was lower in the group with viral infection than in the group without viral infection.

All infections due to RSV, parainfluenza viruses 1 and 3 were diagnosed by IFA, against only $72.7 \%$ of the influenza A virus infections. Viral isolation in cell culture was performed in all 58 newborns that presented negative result to IFA and this was positive in three cases $(5.2 \%)$ caused by influenza A virus. All preterm infants presented negative result to IFA in tracheal aspirates, cell culture and blood culture at admission to the NICU.

RSV and influenza A virus were found throughout the year, but mainly during Fall and Winter. Regarding parainfluenza virus, type 1 was only isolated in Fall, while type 3 was identified during Spring.

Bacterial and fungal infections were diagnosed by blood cultures in all cases. The bacteria and fungi identified as single agents were: Staphylococcus epidermidis (seven cases); Staphylococcus aureus (three cases); Candida albicans (three cases); Streptococcus agalactiae (two cases); Acinetobacter baumanii (two cases); Klebsiella pneumoniae (two cases); Candida parapsilosis (two cases); and Escherichia coli (one case). The eight cases involving association of 

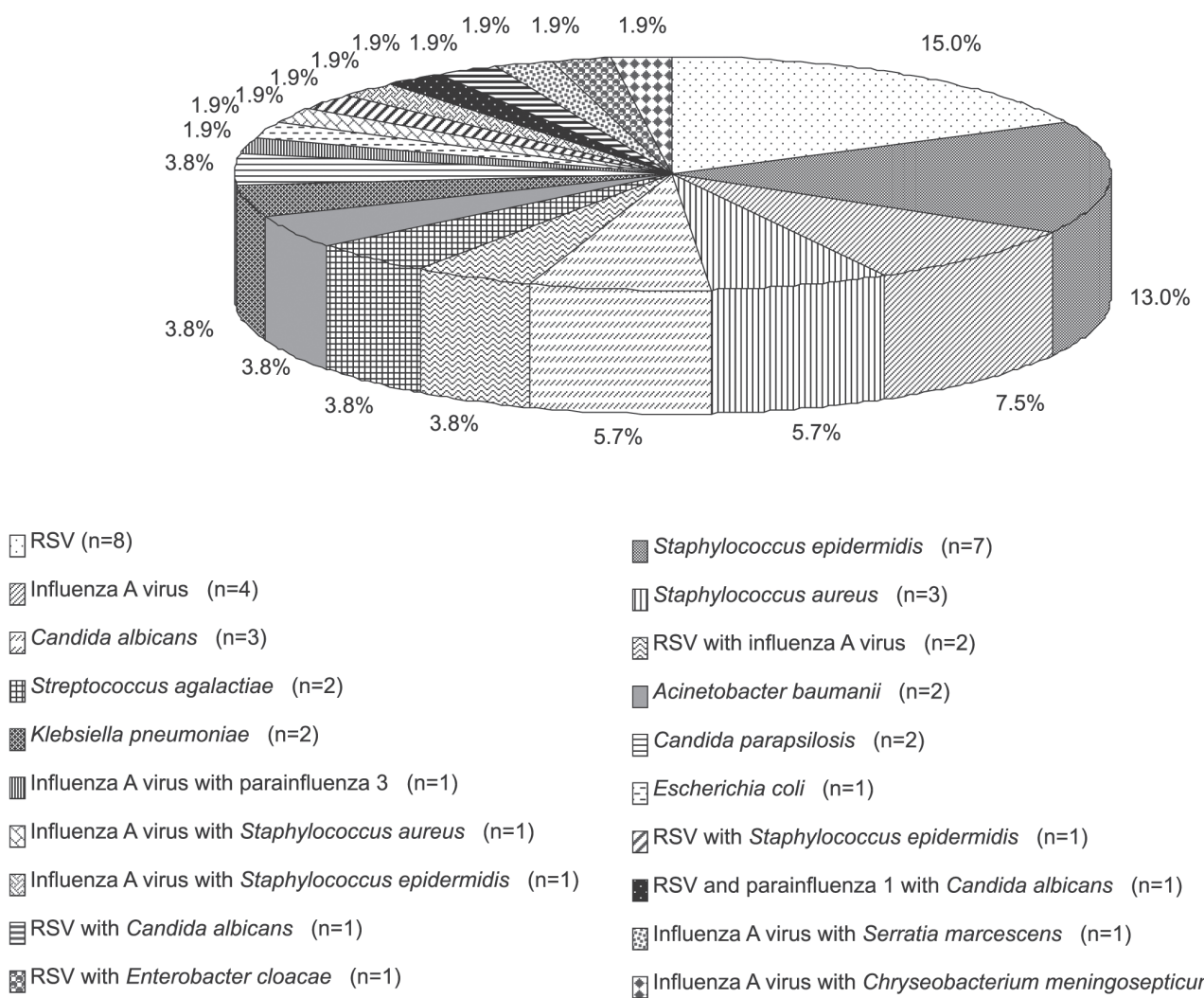

Fig. 1 - Pathogens found in 53 preterm infants with pneumonia.

Table 1

Characteristics of 78 preterm infants submitted to mechanical ventilation, according to group

\begin{tabular}{llll}
\hline Characteristics & Group I $(\mathrm{n}=23)$ & Group II $(\mathrm{n}=55)$ & $p$ Value \\
\hline Sex & $7(30.4 \%)$ & $19(34.5 \%)$ & 0.797 \\
$\quad$ Male & $16(69.6 \%)$ & $36(65.5 \%)$ & \\
$\quad$ Female & $33(26.4-36.6)$ & $32(24-36.5)$ & 0.131 \\
$\begin{array}{l}\text { Gestational age (weeks) } \\
\quad \text { Median (range) }\end{array}$ & $1360(790-3050)$ & $1265(520-2770)$ & 0.330 \\
$\begin{array}{l}\text { Birth weight (g) } \\
\quad \text { Median (range) }\end{array}$ & $1360(790-3120)$ & $1245(520-2770)$ & 0.224 \\
$\begin{array}{l}\text { Weight at admission (g) } \\
\quad \text { Median (range) }\end{array}$ & $4(1-33)$ & $1(1-16)$ & 0.001 \\
$\begin{array}{l}\text { Age at admission (days) } \\
\quad \text { Median (range) }\end{array}$ & $25(8-28)$ & - & - \\
$\begin{array}{l}\text { Age at onset of viral infection (days) } \\
\quad \text { Median (range) }\end{array}$ & $9(7-27)$ & - & - \\
$\begin{array}{l}\text { Length of hospital stay when virus-positive (days) } \\
\quad \text { Median (range) }\end{array}$ & $22(8-139)$ & $13(1-139)$ & 0.138 \\
$\begin{array}{l}\text { Duration of oxygen therapy (days) } \\
\quad \text { Median (range) }\end{array}$ & $7(1-102)$ & $6(1-137)$ & 0.645 \\
$\begin{array}{l}\text { Duration of mechanical ventilation (days) } \\
\text { Median (range) }\end{array}$ & & \\
\hline
\end{tabular}

Group I, with viral infection; Group II, without viral infection 


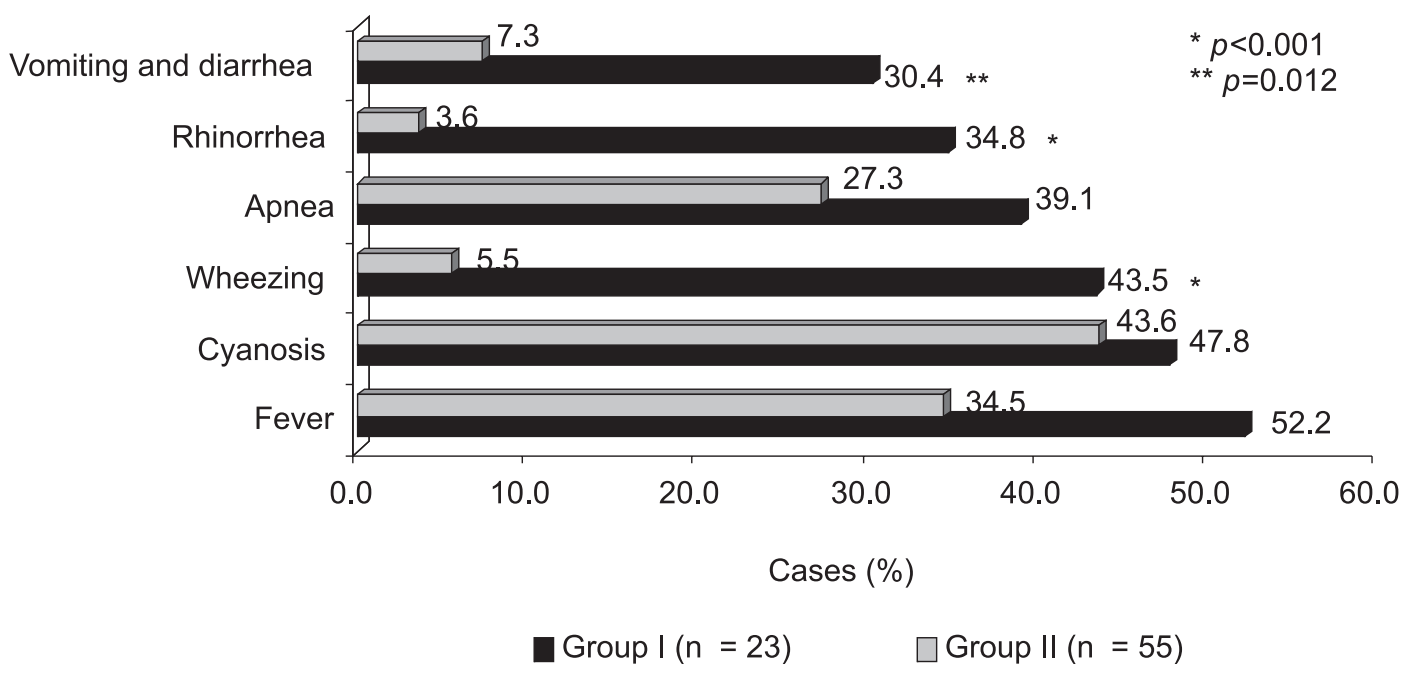

Fig. 2 - Clinical manifestations of 78 preterm infants submitted to mechanical ventilation, according to group (I, with viral infection; II, without viral infection).

Table 2

Laboratory and radiological data of 78 preterm infants submitted to mechanical ventilation, according to group.

\begin{tabular}{|c|c|c|c|}
\hline Parameters & Group I $(\mathrm{n}=23)$ & Group II $(\mathrm{n}=55)$ & $p$ Value \\
\hline \multicolumn{4}{|l|}{ C-reactive protein $(\mathrm{mg} / \mathrm{L})$} \\
\hline$\leq 40$ & $15(65.2 \%)$ & $21(38.2 \%)$ & 0.045 \\
\hline$>40$ & $8(34.8 \%)$ & $34(61.8 \%)$ & \\
\hline \multicolumn{4}{|l|}{ Radiological pattern } \\
\hline Interstitial infiltrate & $15(65.2 \%)$ & $0(0.0 \%)$ & $<0.001$ \\
\hline Alveolar infiltrate & $8(34.8 \%)$ & $30(100.0 \%)$ & \\
\hline
\end{tabular}

Group I, with viral infection; Group II, without viral infection

viral agents with bacteria or fungi were: influenza A virus with Staphylococcus aureus (one case); RSV with Staphylococcus epidermidis (one case); influenza A virus with Staphylococcus epidermidis (one case); RSV and parainfluenza 1 with Candida albicans (one case); RSV with Candida albicans (one case); influenza A virus with Serratia marcescens (one case); RSV with Enterobacter cloacae (one case); and influenza A virus with Chryseobacterium meningosepticum (one case).

The complications and clinical course of the newborns are presented in Fig. 3 and Table 3, respectively. Fifty-three preterm infants submitted to mechanical ventilation $(68 \%)$ had pneumonia and 48 newborns (61.5\%) developed sepsis. No fatal cases occurred among newborns with viral infection, but two patients with mixed infection died during the hospital stay. One of these patients had RSV associated with Candida albicans and the other influenza A virus associated with Chryseobacterium meningosepticum. Both were girls and over three weeks of age at the time of death.

The favorable outcome achieved in most of the cases does not arise from any therapy different than that commonly performed for such bronchopulmonary affections. In $65.2 \%$ of preterm infants with viral infection, low CRP level, negative blood culture and interstitial pneumonia, it was possible to reduce the time of antibiotics prescription (dollars spent with respiratory virus kits: \$ 575; dollars saved with antibiotics: \$ 1050). All preterm infants were provided outpatient follow-up care after discharge, there were 11 readmissions $(17.2 \%)$ in the subsequent period of 90 days due to respiratory symptoms in six infants $(28.6 \%)$ belonging to Group I and five patients (11.6\%) from Group II.

\section{DISCUSSION}

Respiratory viruses contribute significantly to the incidence of nosocomial infection in pediatric patients ${ }^{12,20,24,28,30,34}$. The rates of nosocomial viral lower respiratory tract infection vary in the literature from 23 to $61 \%$ and depend on the type of hospital, on the characteristics of infants attended, on the methods for diagnosis of infections and on the methods used for surveillance ${ }^{32,36}$. The incidence of RSV infection in hospital personnel during community outbreaks has been reported to range from 5 to $61 \%$ depending on the infection control measures used $^{10,14,29}$.

Following the availability of new diagnostic techniques, there has been an increased interest regarding the action of viruses in acute respiratory infections ${ }^{21,25}$. In our study, $29.5 \%$ of the 78 preterm infants with acute respiratory failure and submitted to mechanical ventilation had at least one virus identified, either by IFA in tracheal aspirates or 


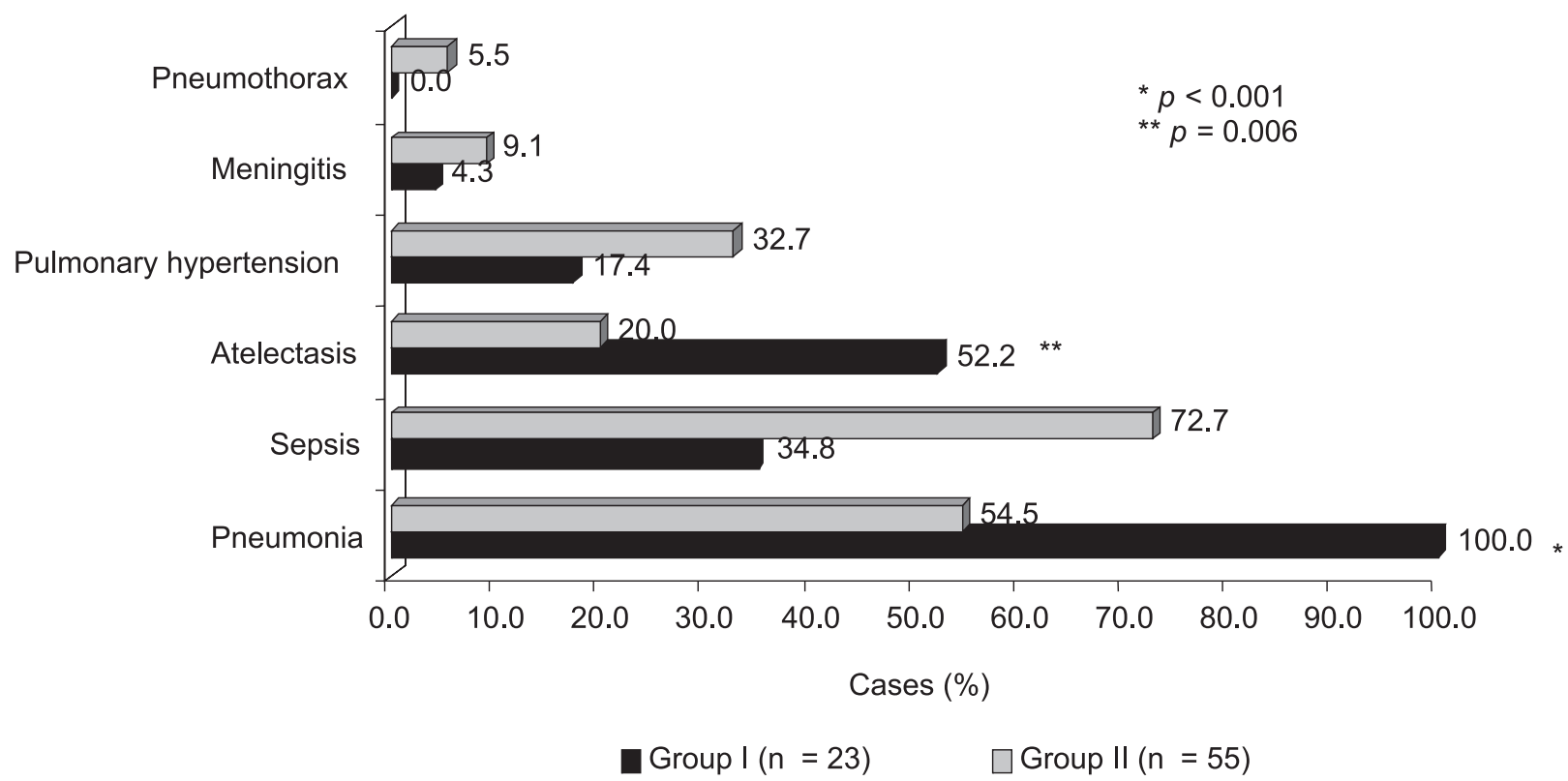

Fig. 3 - Complications of 78 preterm infants submitted to mechanical ventilation, according to group (I, with viral infection; II, without viral infection).

Table 3

Clinical course of 78 preterm infants submitted to mechanical ventilation, according to group

\begin{tabular}{|c|c|c|c|}
\hline Clinical course & Group I $(\mathrm{n}=23)$ & Group II $(\mathrm{n}=55)$ & $p$ Value \\
\hline \multicolumn{4}{|c|}{ Duration of respiratory distress (days) } \\
\hline Median (range) & $14(5-139)$ & $12(1-139)$ & 0.230 \\
\hline Hospital discharge & $21(91.3 \%)$ & $43(78.2 \%)$ & 0.205 \\
\hline \multicolumn{4}{|c|}{ Length of hospital stay (days) } \\
\hline Median (range) & $32(11-141)$ & $41(7-142)$ & 0.755 \\
\hline Mortality & $2(8.7 \%)$ & $12(21.8 \%)$ & \\
\hline \multicolumn{4}{|c|}{ Length of hospital stay (days) } \\
\hline Median (range) & $94(28-160)$ & $20(1-114)$ & 0.131 \\
\hline
\end{tabular}

Group I, with viral infection; Group II, without viral infection

by cell culture. RSV was the most frequent virus $(14.1 \%)$ in preterm infants submitted to mechanical ventilation. There was a similarity between this data and that described in studies performed in developed countries, where RSV is considered to be the principal viral agent of lower respiratory tract infections, with rates of 5 to $40 \%$ in cases of pneumonia ${ }^{2,3,5,13}$.

At least one etiologic agent was found in 45 preterm infants with pneumonia $(84.9 \%)$ in this sample, a proportion similar to that described in previous studies (40 to $85 \%)^{8,17}$. The possibility of an etiologic diagnosis increases in proportion to the number and sensitivity of laboratorial methods used to test for the most common agents in childhood. The literature mentions positivity of blood cultures varying between 10 and $80 \%$, depending on the etiologic agent and on the culture medium used ${ }^{8}$. In the present study, the positivity of hemocultures was $38.5 \%$ (30 cases). Mixed lower respiratory tract infections are not uncommon, varying from 16 to $30 \%$, especially in children under two years old ${ }^{18,23,35}$. Hence, the data of the present work appears to correspond to the etiologic patterns described by these authors.

With respect to sex, gestational age, birth weight, weight at admission, duration of oxygen therapy and mechanical ventilation, there was no significant difference in the identification, or non-identification of the viruses (Table 1). These data were similar to those reported by MIYAO et al. (1999)22, who likewise found no association between viral infection and sex or nutritional state. The group without viral infection (Group II) was associated with a lower age at hospital admission.

Mild or asymptomatic viral lower respiratory tract infections are not common in infants under two months of age, especially when premature, and the latter may show septic syndrome, apnea, hypothermia, bronchial hyperreactivity and atelectasis ${ }^{11}$. HALL et al. $(1979)^{14}$ and MEISSNER et al. (1984) $)^{21}$ have reported that both premature and full-term newborns with infection caused by RSV present 
atypical clinical manifestations such as anorexia, lethargy and irritability, which renders diagnosis of these patients somewhat difficult. Regarding the clinical signs and symptoms observed in the preterm infants of this sample, wheezing, rhinorrhea, vomiting and diarrhea were significantly more frequent among those with viral infection (Group I) ( $p<0.001, p<0.001$ and $p=0.012$, respectively) (Fig. 2). According to these results, it was possible to affirm that young neonates with viral infection also develop important respiratory problems, on the contrary to that previously described by the above authors.

Evaluation of CRP may help to differentiate between bacterial and viral etiology. A statistically significant association was found between nosocomial viral lower respiratory tract infection and levels of CRP less than or equal to $40 \mathrm{mg} / \mathrm{L}(p=0.045)$ (Table 2$)$. The authors observed that eight preterm infants with bacterial or fungal co-infection presented CRP concentrations above $40 \mathrm{mg} / \mathrm{L}$. All preterm infants in this study with confirmed bacterial or fungal infection also presented CRP levels above $40 \mathrm{mg} / \mathrm{L}$. PUTTO et al. (1986) ${ }^{26}$, studying 154 children with fever, reported that values of CRP between 20 and $40 \mathrm{mg} / \mathrm{L}$ may be found in both viral and bacterial infections, and that levels over 40 $\mathrm{mg} / \mathrm{L}$ detect $79 \%$ of the bacterial infections, with $90 \%$ specificity. SAIJO et al. (1996) ${ }^{27}$ observed that most of the children with infection caused by RSV present a low CRP level. A low CRP level suggests a single viral infection and depending upon the clinical and radiological course, enables the suspension of antibiotic therapy and a reduction in the hospital stay.

A statistically significant correlation was found between nosocomial viral lower respiratory tract infection and interstitial infiltrate $(p<$ 0.001 ) (Table 2). All patients with confirmed bacterial, fungal or mixed infection presented alveolar infiltrate. These results corroborate the literature and indicate that the presence of alveolar infiltrate in the chest radiography is a sign of bacterial pneumonia. Interstitial infiltrate was more frequent in viral infections. Previous studies have not found a correlation between etiologic agent and radiological pattern ${ }^{18}$.

Viral identification by IFA and/or cell culture is widely recognized in the literature as a method to test for respiratory viruses ${ }^{4}$. Use of both these diagnostic methods appears to have contributed significantly to a result closer to reality, since each technique complemented the other. In view of the great positivity achieved with IFA, the authors consider it is reasonable to use this as a test for respiratory viruses, but nevertheless the importance of cell culture in the case of infection caused by influenza viruses should be emphasized.

Regarding complications in these preterm infants, there was an association between nosocomial viral respiratory infection and pneumonia $(p<0.001)$ and atelectasis $(p=0.006)$ (Fig. 3). No significant differences were detected between the two groups and the duration of respiratory distress (Table 3 ).

Despite the potential lethality previously attributed to respiratory viruses and particularly $\mathrm{RSV}^{1,16}$, the authors did not observe any fatal cases among the preterm infants with viral infection alone. All 14 patients $(17.9 \%)$ that died during this study presented bacterial or fungal infection either in isolation or concomitant to the viral infection (Table 3 ). In the group with nosocomial viral infection, $30.4 \%$ of the infants had congenital heart disease (seven cases) and $13 \%$ of the patients presented bronchopulmonary dysplasia (three cases); and in the group without viral infection, there were $40 \%$ with congenital heart disease (22 cases) and $18.2 \%$ with bronchopulmonary dysplasia (10 cases). The two groups of preterm infants submitted to mechanical ventilation were similar in terms of length of stay.

The correlation verified in this study and by other authors between lower respiratory tract infection and detection of virus does not allow the conclusion, however, that these agents are the only ones involved, or even that they are directly responsible for all the alterations present in the lower airway ${ }^{4}$. Therefore, we consider that definite conclusions about the etiopathogenesis of lower respiratory tract infections can not be established from the current study. The same is true for almost all the other studies that collected and analyzed only samples of tracheal secretion and blood cultures. The noninvasive techniques for collection of respiratory secretion are more practical and offer lower risk for preterm infants than the invasive techniques (bronchoalveolar lavage).

The methodological limitation in our study does not, however, undermine the usefulness of this type of investigation, since significant conclusions were obtained. We verified that the viral agents participated, at the least, as an originating factor of severe lower respiratory tract infections. Another relevant aspect of this study concerns the age of children infected by the viral agents, demonstrating that in the neonatal period there is also a need to carry out specific diagnostic exams. This conclusion contradicts studies published up until now, which report that infection caused by respiratory viruses, and even by RSV are rare in newborns due to the high level of maternal antibodies and the limited contact with other people $\mathrm{e}^{14}$. To our knowledge no systematic investigations into respiratory viruses among preterm infants with acute respiratory failure have been reported in Brazil. The confirmation of a viral infection diagnosis is important for rationalizing the prescription of antibiotics, thereby avoiding the appearance of multi-resistant bacteria and to control the dissemination of respiratory viruses in NICUs ${ }^{7,15,19}$.

We conclude that, RSV was the most frequent virus among the preterm infants of this study. We also observed that although the majority of nosocomial viral lower respiratory tract infections had a favorable outcome, some patients presented a severe and prolonged clinical manifestation, mainly when there was concomitant bacterial or fungal infection. Low CRP levels and interstitial infiltrate were associated with viral infection. The use of both IFA and cell culture was important for the diagnosis of viral infections, since each technique complemented the other. It was possible to reduce the time of prescription of antibiotics in $65.2 \%$ of the preterm infants with nosocomial viral lower respiratory tract infection. These findings indicate the need to develop prophylactic measures and antiviral therapeutics suitable for infants in the neonatal period, in addition to rendering methods for viral diagnosis more accessible to physicians.

\section{RESUMO}

\section{Incidência de vírus respiratórios em crianças pré-termo externas submetidas à ventilação mecânica}

Os objetivos do estudo foram determinar a incidência de infecção por vírus respiratórios em crianças pré-termo externas submetidas à 
ventilação mecânica e avaliar os padrões clínico, laboratorial e radiológico das infecções virais entre crianças pré-termo internadas em unidade de cuidados intensivos neonatal (NICU) com insuficiência respiratória aguda de qualquer tipo. Setenta e oito crianças pré-termo externas foram estudadas de Novembro de 2000 a Setembro de 2002. Os recém-nascidos foram classificados em dois grupos: com infecção viral (Grupo I) e sem infecção viral (Grupo II). Vírus respiratórios foram diagnosticados em 23 crianças pré-termo (29,5\%); o vírus mais importante foi o sincicial respiratório (VSR) (14,1\%), seguido pelo vírus influenza A (10,2\%). Rinorréia, sibilância, vômitos e diarréia, pneumonia, atelectasia e infiltrado intersticial foram significativamente mais freqüentes nos recém-nascidos com infecção viral hospitalar. Houve correlação entre infecção viral hospitalar e valores baixos de proteína C-reativa. Dois pacientes com infecção mista do Grupo I faleceram durante a internação. Em conclusão, o VSR foi vírus mais incidente nestes pacientes com infecção nosocomial do trato respiratório inferior. Foi observado que, embora a maioria das infecções respiratórias virais tenham tido uma evolução favorável, alguns pacientes apresentaram quadro clínico grave e prolongado, principalmente quando houve infecção bacteriana ou fúngica concomitante.

\section{ACKNOWLEDGEMENTS}

The authors extend their thanks to the Laboratory of the Children's Institution, Hospital das Clinicas da Faculdade de Medicina da Universidade de São Paulo for CRP determinations and blood cultures.

\section{REFERENCES}

1. ANDERSON, L.J.; PARKER, R.A. \& STRIKAS, R.L. - Association between respiratory syncytial virus outbreaks and lower respiratory tract deaths of infants and young children. J. infect. Dis., 161: 640-646, 1990.

2. ATKINS, J.T.; KARIMI, P.; MORRIS, B.H.; McDAVID, G. \& SHIM, S. - Prophylaxis for respiratory syncytial virus with respiratory syncytial virus-immunoglobulin intravenous among preterm infants of thirty-two weeks gestation and less: reduction in incidence, severity of illness and cost. Pediat. infect. Dis. J., 19: 138-143, 2000.

3. BERMAN, S. - Epidemiology of acute respiratory infections in children of developing countries. Rev. infect. Dis., 13(suppl.6): S454-S462, 1991.

4. BOYER, K.M. - Nonbacterial pneumonia. In: FEIGIN, R.D., ed. Textbook of pediatric infectious diseases. 4. ed. Philadelphia, Saunders, 1998. p. 260-273.

5. CARBONELl-ESTRANY, X.; QUERO, J.; BUSTOS, G. et al. - Rehospitalization because of respiratory syncytial virus infection in premature infants younger than 33 weeks of gestation: a prospective study. IRIS Study Group. Pediat. infect. Dis. J., 19: 592-597, 2000.

6. DINIZ, E.M.A.; VIEIRA, R.A.; ISHIDA, M.A. et al. - Clinical and laboratorial evaluation of neonates with respiratory syncytial virus pneumonia. In: WORLD CONGRESS OF PERINATAL MEDICINE, 4., Buenos Aires, 1999. Proceedings. Bologna, Monduzzi, 1999. p. 59-62.

7. DINIZ, E.M.A.; VIEIRA, R.A.; ISHIDA, M.A. et al. - Infection by influenza A virus in preterm newborn infants. Prenat. Neonat. Med., 6: 358-362, 2001.

8. DRUMMOND, P.; CLARK, J.; WHEELER, J. et al. - Community acquired pneumonia: a prospective UK study. Arch. Dis. Child., 83: 408-412, 2000.

9. ENARSON, D.A. \& CHRETIEN, J. - Epidemiology of respiratory infectious diseases. Curr. Opin. pulm. Med., 5: 128-135, 1999.
10. FORD-JONES, E.L. - The special problems of nosocomial infection in pediatric patient In: WENZEL, R.P., ed. Prevention and control of nosocomial infections. 2. ed. Baltimore, Williams \& Wilkins, 1993. p. 812-896.

11. FORSTER, J. \& SCHUMACHER, R.F. - The clinical picture presented by premature neonates infected with the respiratory syncytial virus. Europ. J. Pediat., 154: 901905,1995

12. GOLDWATER, P.N.; MARTIN, A.J.; RYAN, B. et al. - A survey of nosocomial respiratory viral infections in a children's hospital: occult respiratory infection in patients admitted during an epidemic season. Infect. Control Hosp. Epidem., 12: 231-238, 1991.

13. GROSS, M.; BRUNE, T.; JORCH, G.; RABE, H. \& HENTSCHEL, R. - Significance of respiratory syncytial virus (RSV) infection in the $1^{\text {st }}$ year of life. Infection, 28: $34-$ 37,2000 .

14. HALL, C.B.; KOPELMAN, A.E.; DOUGLAS Jr., R.G.; GEIMAN, J.M. \& MEAGHER, M.P. - Neonatal respiratory syncytial virus infection. New Engl. J. Med., 300: 393$396,1979$.

15. HORCAJADA, J.P.; PUMAROLA, T.; MARTINEZ, J.A. et al. - A nosocomial outbreak of influenza during a period without influenza epidemic activity. Europ. Respir. J., 21: 303-307, 2003.

16. JOFFE, S.; ESCOBAR, G.J.; BLACK, S.B.; ARMSTRONG, M.A. \& LIEU, T.A. Rehospitalization for respiratory syncytial virus among premature infants. Pediatrics, 104: 894-899, 1999

17. JUVÉN, T.; MERTSOLA, J.; WARIS, M. et al. - Etiology of community-acquired pneumonia in 254 hospitalized children. Pediat. infect. Dis. J., 19: 293-298, 2000.

18. KORPPI, M.; HEISKANEN-KOSMA, T.; JALONEN, E. et al. - Aetiology of communityacquired pneumonia in children treated in hospital. Europ. J. Pediat., 152: 24-30, 1993.

19. LEVY, J. - The pediatric patient. In: WENZEL, R.P., ed. Prevention and control of nosocomial infections. 3. ed. Baltimore, Williams \& Wilkins, 1997. p. 1039-1058.

20. MEIBALANE, R.; SEDMAK, G.V.; SASIDHARAN, P.; GARG, P. \& GRAUSZ, J.P. Outbreak of influenza in a neonatal intensive care unit. J. Pediat., 91: 974-976, 1977.

21. MEISSNER, H.C.; MURRAY, S.A.; KIERNAN, M.A.; SNYDMAN, D.R. \& McINTOSH, K. - A simultaneous outbreak of respiratory syncytial virus and parainfluenza virus type 3 in a newborn nursery. J. Pediat., 104: 680-684, 1984.

22. MIYAO, C.R.; GILIO, A.E.; VIEIRA, S. et al. - Infecções virais em crianças internadas por doença aguda do trato respiratório inferior. J. Pediat. (Rio de J.), 75: 334-344, 1999.

23. NOHYNEK, H.; ESKOLA, J.; LAINE, E. et al. - The causes of hospital-treated acute lower respiratory tract infection in children. Amer. J. Dis. Child., 145: 618-622, 1991.

24. OKUONGHAE, H.O.; NWANKWO, M.U.; OKOLO, A.A. \& SCHUIT, K.E. Nosocomial respiratory syncytial virus infection in a newborn nursery. Ann. trop. Paediat., 12: 185-193, 1992.

25. PROBER, C.G. \& SULLENDER, W.M. - Advances in prevention of respiratory syncytial virus infections. J. Pediat., 135: 546-558, 1999.

26. PUTTO, A.; RUUSKANEN, O.; MEURMAN, O. et al. - C-reactive protein in the evaluation of febrile illness. Arch. Dis. Child., 61: 24-29, 1986.

27. SAIJO, M.; ISHII, T.; KOKUBO, M. et al. - White blood cell count, C-reactive protein and erythrocyte sedimentation rate in respiratory syncytial virus infection of the lower respiratory tract. Acta paediat. jap., 38: 596-600, 1996.

28. SINGH-NAZ, N.; WILLY, M. \& RIGGS, N. - Outbreak of parainfluenza virus type 3 in a neonatal nursery. Pediat. infect. Dis. J., 9: 31-33, 1990. 


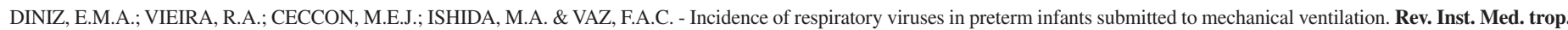
S. Paulo, 47(1):37-44, 2005.

29. STEVENS, T.P.; SINKIN, R.A.; HALL, C.B.; MANISCALCO, W.M. \& McCONNOCHIE, K.M. - Respiratory syncytial virus and premature infants born at 32 weeks' gestation or earlier. Hospitalization and economic implications of prophylaxis. Arch. Pediat. adolesc. Med., 154: 55-61, 2000.

30. STOLL, B.J. - The global impact of neonatal infection. Clin. Perinatol., 24: 1-21, 1997.

31. STRETTON, M.; AJIZIAN, S.J.; MITCHELL, I. \& NEWTH, C.J. - Intensive care course and outcome of patients infected with respiratory syncytial virus. Pediat. Pulmonol., 13: $143-150,1992$.

32. TURNER, R.B. - Nosocomial viral respiratory infections in pediatric patients. In: MAYHALL, C.G., ed. Hospital epidemiology and infection control. Baltimore, Williams \& Wilkins, 1996. p. 485-493.

33. VALENTI, W.M.; MENEGUS, M.A.; HALL, C.B.; PINCUS, P.H. \& DOUGLAS Jr., R.G. - Nosocomial viral infections: I. Epidemiology and significance. Infect. Control., 1: 33-37, 1980.
34. VALENTI, W.M. - Selected viruses of nosocomial importance. In: BENNETT, J.V.; BRACHMAN, P.S., ed. Hospital infections. 3. ed. Boston, Little, Brown, 1992. p. 789-821.

35. VIEIRA, R.A.; DINIZ, E.M.A. \& VAZ, F.A.C. - Clinical and laboratory study of newborns with lower respiratory tract infection due to respiratory viruses. J. Matern. Fetal Neonatal Med., 13: 341-350, 2003.

36. WELLIVER, R.C. \& McLAUGHLIN, S. - Unique epidemiology of nosocomial infection in a children's hospital. Amer. J. Dis. Child., 138: 131-135, 1984.

Received: 16 April 2004

Accepted: 16 November 2004 